\title{
Neuroendocrine Carcinoma of the Bladder
}

\author{
Takashi Kawahara $^{\mathrm{a}}$ Shoji Yamanaka ${ }^{\mathrm{b}}$ Hisashi Ohshiro ${ }^{\mathrm{b}}$

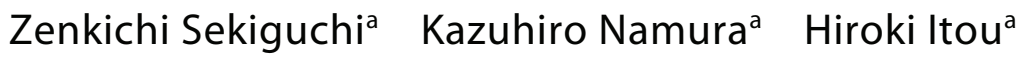 \\ Futoshi Sano $^{a}$ Kaoru Kita ${ }^{a}$ Narihiko Hayashi ${ }^{a}$ \\ Kazuhide Makiyama ${ }^{a}$ Noboru Nakaigawa ${ }^{a}$ \\ Takehiko Ogawa $^{a}$ Hiroji Uemura ${ }^{a}$ Masahiro Yao ${ }^{a}$ \\ Yoshinobu Kubota ${ }^{a}$ \\ aDepartment of Urology, Yokohama City University Graduate School of Medicine, \\ ${ }^{b}$ Department of Pathology, Yokohama City University Hospital, Yokohama, Japan
}

\section{Key Words}

Neuroendocrine tumor · Bladder tumor · Bladder cancer

\begin{abstract}
The case was a 67-year-old male who visited our hospital with a major complaint of macroscopic hematuria. A bladder tumor was found. When a transurethral resection of the bladder tumor was performed, the histopathological diagnosis was neuroendocrine bladder cancer. After chemotherapy with cisplatin and etoposide a partial shrinkage of the tumor was observed; however, the patient expired 7 months after the first visit.
\end{abstract}

\section{Introduction}

Primary neuroendocrine cancer of the bladder is a rare histological occurrence, constituting $0.48-1 \%$ of all bladder cancers. The 5 -year survival rate is around $8 \%$ and the prognosis is extremely unfavorable. Due to the morphology of the tumor, treatments based on small cell lung cancer have been performed. In this study, we treated a case in which chemotherapy was performed with cisplatin (CDDP) and etoposide (VP-16) for neuroendocrine cancer that occurred in the bladder; here, we report the results.

\section{Case Report}

Our patient was a 67-year-old male with a major complaint of macroscopic hematuria. His previous history included a traumatic brain hemorrhage at the age of 60 years and stomach cancer at the age of 64 years. He had no family history in particular. 


\begin{tabular}{c|l|l|l}
$\begin{array}{c}\text { Case Reports in } \\
\text { Oncology }\end{array}$ & $\begin{array}{l}\text { Case Rep Oncol 2010;3:54-58 } \\
\text { Dol: } 10.1159 / 000289584\end{array}$ & & $\begin{array}{l}\text { Published online: March 3, 2010 S. Karger AG, Basel } \\
\text { ISSN 1662-6575 } \\
\text { www.karger.com/cro }\end{array}$ \\
\hline
\end{tabular}

\section{Current Medical History}

In February 2009, the patient noticed blood in his urine and visited our department. A cystoscopy revealed a nodular tumor on the right bladder wall. An MRI and bone scintigraphy revealed metastasis to both external iliac lymph nodes, resulting in a diagnosis of clinical stage T3bN2M0. In March 2009, the patient was hospitalized for the purpose of undergoing a transurethral resection of the bladder tumor (TUR-Bt).

\section{Laboratory Data at the Time of Admission}

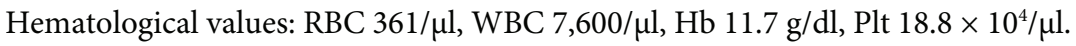

Biochemistry: Alb 4.5 g/dl, TP 7.0 g/dl, T-bil 0.5 mg/dl, AST 16 IU/l, ALT 12 IU/l, ALP 263 IU/l, LDH 178 IU/l, BUN 16 mg/dl, Cre 0.84 mg/dl, Na 139 mEq/l, K 4.7 mEq/l, Cl 102 mEq/l, CRP 0.07 g/dl.

Urinary analysis: $\mathrm{pH} 5.5, \mathrm{RBC}>51 / \mathrm{hpf}, \mathrm{WBC} 11-20 / \mathrm{hpf}$, protein (2+), glucose (-).

Urinary cytology: class IIIb.

\section{Image Findings}

Simple pelvic MRI revealed a high basic tumorous lesion with low signals for T1WI, high signals for T2WI, and a diameter of $4 \mathrm{~cm}$ on the right bladder wall, and invasion outside the wall was observed. In the external iliac artery regions on both sides, enlarged lymph nodes with a diameter of $1.5 \mathrm{~cm}$ were observed. No obvious distal metastasis was detected by bone scintigraphy and thoracic pelvic CT.

\section{Post-Admission Course}

In March 2009, a TUR-BT was immediately performed for the purpose of obtaining a pathological diagnosis. In the histopathological findings, there were a number of large and small solid alveoli of atypical cells accompanied by infiltrative growth into the interstitium. The atypical cells had a high N/C ratio and rough chromatin, and the neoplastic alveoli also suggested differentiation into the neuroendocrine system (fig. 1a). When immunohistological staining was performed, the tumor cells were partially positive for CD56 and chromogranin A and negative for synaptophysin (fig. 1b). Based on the morphology and the results of immunohistological staining, the patient was diagnosed with neuroendocrine cancer.

\section{Post-Operative Course}

In June 2009, the patient was hospitalized for the purpose of undergoing additional treatment. The NSE upon admission was $260 \mathrm{ng} / \mathrm{ml}$. A positron emission tomography-computed tomography (PETCT) performed before chemotherapy revealed metastasis to the liver, bones, and lymph nodes (fig. 2). Based on the protocol for small cell lung cancer, chemotherapy with cisplatin (CDDP) and etoposide (VP-16) was performed along with PE therapy (P: $80 \mathrm{mg} /$ body, E: $100 \mathrm{mg} /$ body). The NSE after completing the first course declined to $9.1 \mathrm{ng} / \mathrm{ml}$ and CT also revealed tumor shrinkage (fig. 3 ).

However, before implementing the second course, the patient's systemic condition deteriorated, and in August 2009, the patient expired due to multiple systemic metastases.

\section{Discussion}

Since first being reported by Cramer et al. in 1981 [1], neuroendocrine bladder cancer has often been reported as primary small cell cancer of the bladder. Histologically, it is believed that this condition exhibits a similar histological appearance as small cell lung cancer, where the tumor cells are small, the nuclei are rich in chromatin and are circular or spindle-shaped, and tumor cells with scarce cytoplasm solidly proliferate. For immunostaining, CD56, synaptophysin, and chromogranin A are used. In this study, 


\begin{tabular}{c|l|l|l}
$\begin{array}{c}\text { Case Reports in } \\
\text { Oncology }\end{array}$ & $\begin{array}{l}\text { Case Rep Oncol 2010;3:54-58 } \\
\text { D0I: 10.1159/000289584 }\end{array}$ & Published online: March 3, 2010 & $\begin{array}{l}\text { O 2010 S. Karger AG, Basel } \\
\text { ISSN 1662-6575 } \\
\text { www.karger.com/cro }\end{array}$ \\
\hline
\end{tabular}

CD56 and chromogranin A were shown to be partially positive. The case in this study involved a high-grade neuroendocrine cancer according to the World Health Organization classification, and using the classifications of lung cancer, many parts had morphologies equivalent to those of small cell cancer, while some parts exhibited morphologies of large cell cancer.

Blomjous et al. [2] have reported that primary neuroendocrine cancer of the bladder constitutes approximately $0.48 \%$ of all bladder tumors in autopsy cases. At the time of diagnosis, primary neuroendocrine cancer of the bladder is detected as an advanced cancer occurring in $\mathrm{T} 3$ and $\mathrm{T} 4$ in $70 \%$ and $16.3 \%$ of cases, respectively. In addition, the 5year survival rate has been reported to be $8.1-19 \%$, and the prognosis is extremely unfavorable $[2,3]$. In our present case, too, the cancer progressed rapidly and resulted in death 6 months after diagnosis.

Regarding treatment, multimodality therapy combining surgical therapy and chemotherapy/radiation therapy is often implemented; however, this is not yet an established therapy. Based on cases of small cell lung cancer, chemotherapy is mainly performed with PE therapy using a combination of cisplatin (CDDP) and etoposide (VP16), and there are reports in which the prognosis was improved [4]. In this study, we also performed PE therapy based on small cell lung cancer and observed a decrease in the NSE value and a shrinkage of the tumor on CT images.

As primary neuroendocrine cancer of the bladder progresses rapidly, we believe that it is important to select multimodality therapy via early detection.

Fig. 1. a Hematoxylin-eosin stain $(\times 400)$. b CD56 (×400).
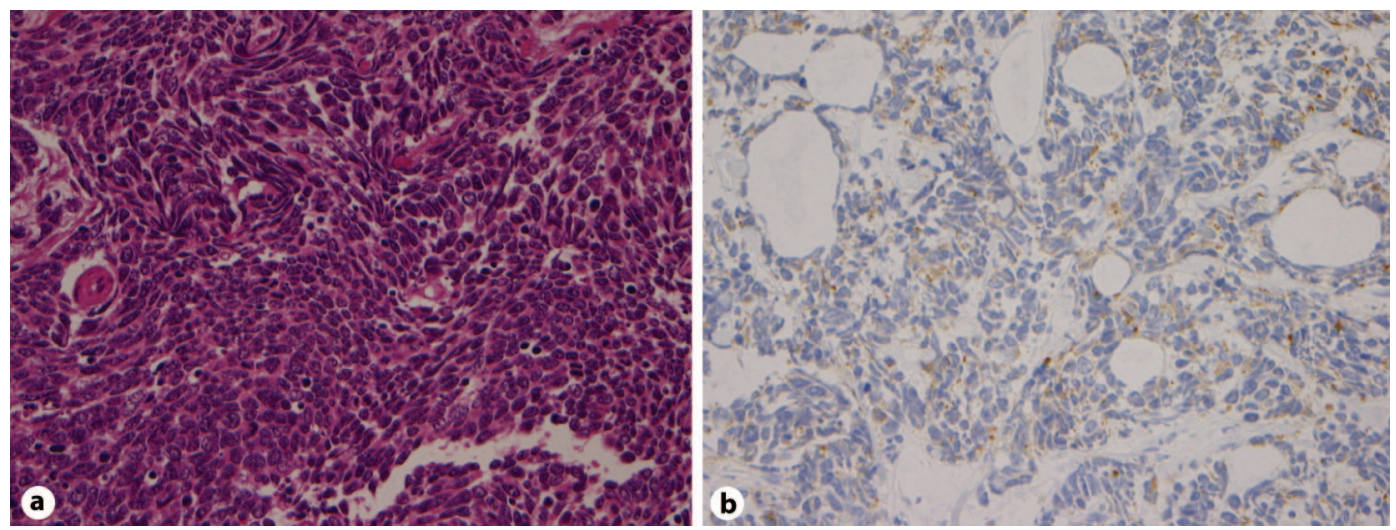


\begin{tabular}{r|l|l|l}
$\begin{array}{r}\text { Case Reports in } \\
\text { Oncology }\end{array}$ & $\begin{array}{l}\text { Case Rep Oncol 2010;3:54-58 } \\
\text { D0I: 10.1159/000289584 }\end{array}$ & Published online: March 3, 2010 & $\begin{array}{l}\text { O 2010 S. Karger AG, Basel } \\
\text { ISSN 1662-6575 } \\
\text { www.karger.com/cro }\end{array}$ \\
\hline
\end{tabular}

Fig. 2. PET-CT. a Liver. b, c Bone. $\mathbf{d}$ Lymph node metastases.
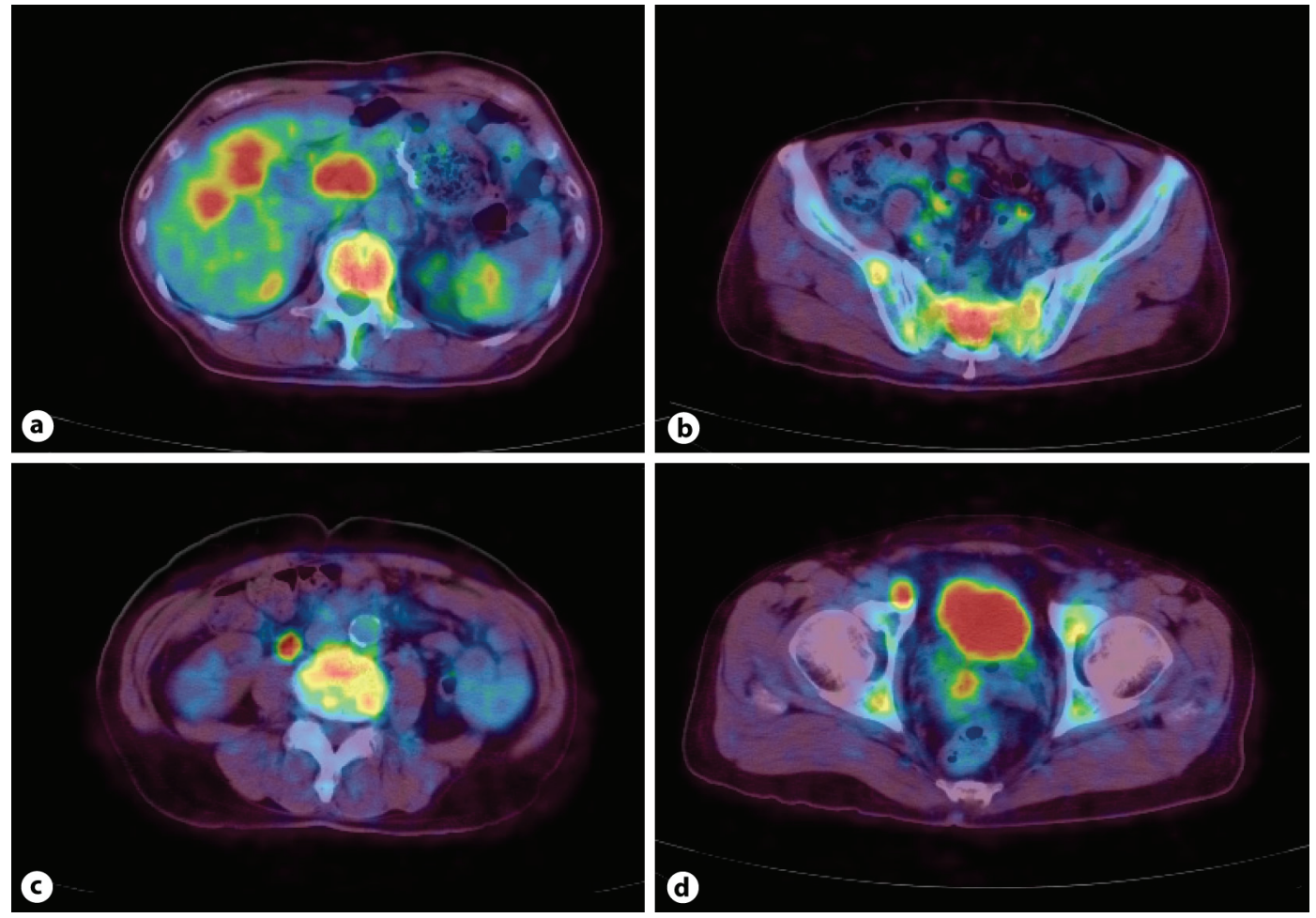

Fig. 3. CT of abdomen. a, c Before chemotherapy. b, d After chemotherapy.
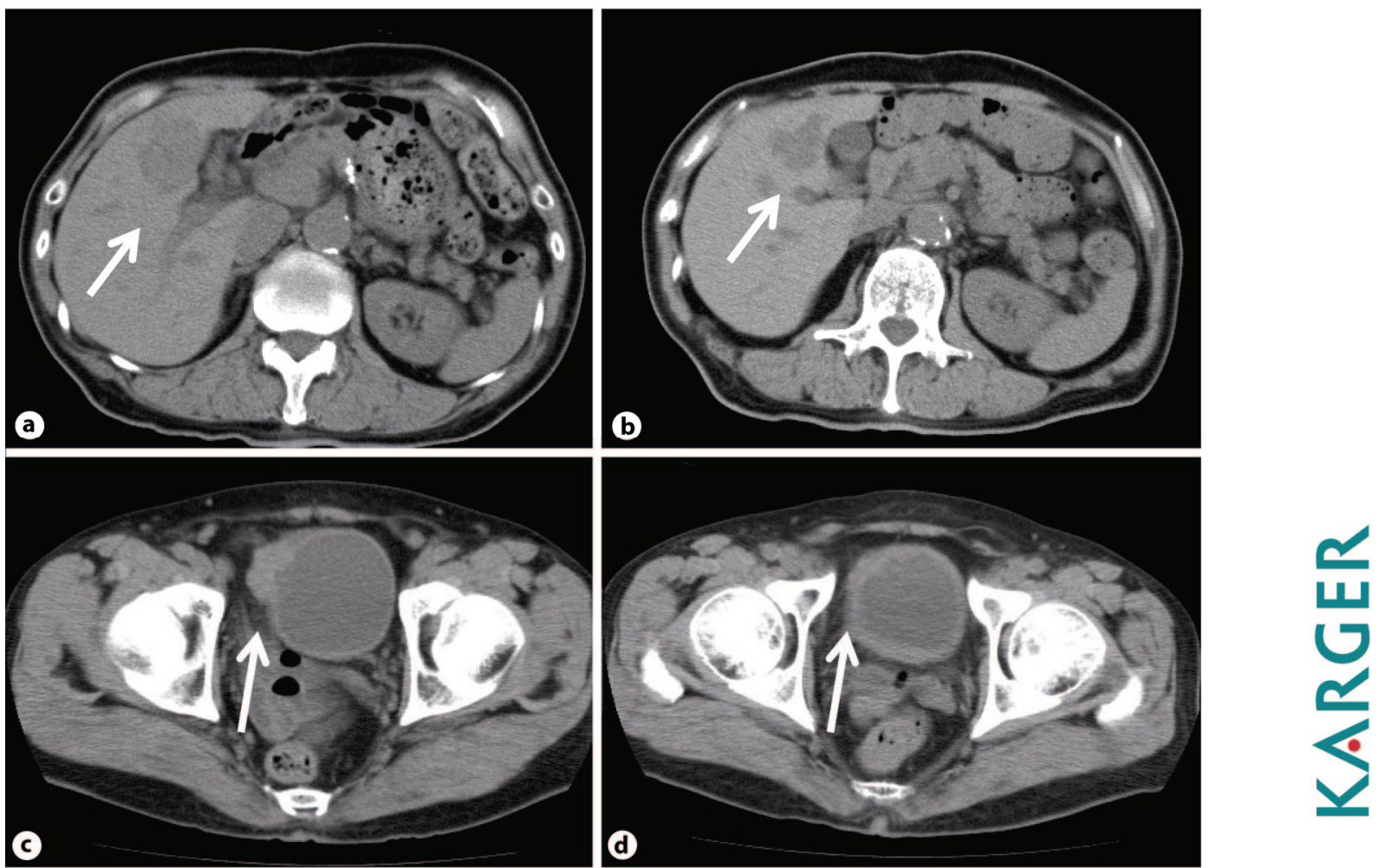


\section{References}

1 Cramer SF, Aikawa M, Cebelin M: Neurosecretory granules in small cell invasive carcinoma of the urinary bladder. Cancer 1981;47:724-730.

2 Blomjous CE, Vos W, Schipper NW, et al: Morphometric and flow cytometric analysis of small cell undifferentiated carcinoma of the bladder. J Clin Path 1989;42:1032-1039.

-3 Abbas F, Civantos F, Benedetto P, et al: Small cell carcinoma of the bladder and prostate. Urology 1995;46:617-630.

4 Mackey JR, Au HJ, Venner P, et al: Genetourinary small cell carcinoma of the bladder: a report of 25 cases. J Urol 1998;153:1820-1822. 